\title{
Effect of Biochar, Compost, Chicken Manure and Mineral Fertilization on Total Uptake of NPK of Wheat and Barley in Sandy Soil
}

Hassin AL. Makhlof*

Dept. of Soil and Water, Faculty of Agriculture, Sirte University, Libya
Hassan A. Mohammed

Dept. of Soil and Water, Faculty of Agriculture, Sirte University, Libya

\section{Gomoa L. Ahmed}

Dept. of Soil, Faculty of Agriculture, Mansoura University, Egypt

hassin.maklof@su.edu.ly

https://doi.org/10.36602/jmuas.2019.v01.01.11

\begin{abstract}
Wheat and barley are the most important agricultural crops in many countries around the world, just behind rice and maize in importance. Hence, two field experiments with design of spit plot were carried out in winter season of 2014-2015 at the Faculty of Agriculture Research Farm, Mansoura University, Egypt to investigate total uptake of N, P and K by wheat (Sakha 68) and barley (Gemeza123) under different application rates of mineral and organic fertilizers, as well as grain Protein yield of $\mathrm{Kg} \mathrm{fed}^{-1}$. Treatments of organic were chicken manure, compost and biochar, while the studied mineral fertilizer treatments took with rates of 50,75,100 and $125 \%$.The results revealed that total removed (uptake) of NPK by wheat plant were $80.88,15.79$, and 123.54 , respectively; while with barley plant they amounted by $61.60,11.21$, and 56.83 were assigned with the treatment of chicken manure $+125 \%$ of recommended NPK treatments. Also, the best interaction was found between chicken manure $+125 \%$ mineral treatments which gave the highest value of protein uptake which were 310.60 and $278.76 \mathrm{~kg}$ fed-1 compared with other interactions of wheat and barley crops. It can conclude that Chicken manure $+125 \%$ mineral treatments were the superior in most amendments and gave the highest values of total NPK uptake and protein yield which in turn lead to improve crop productivity as well as sustain soil health and fertility.
\end{abstract}

Key words: Chicken manure-compost-biochar-mineral fertilization-wheat-barley.

\section{Introduction}

Wheat (Triticum aestivum L.) is one of the most important cereal crop for the public of Egypt, and considers as a strategic crop. It represents approximately $10 \%$ of the total agricultural production value and about $20 \%$ of all agricultural imports. Furthermore, barley (Hordeum distichon $\mathrm{L}$ ) is the essential food for a huge part of the world population. In Egypt, the total cultivated area is 75.479 hectares with overall production of 149. 238 thousand tons (FAO 2009).

Wheat and barley growing can be found in modern reclaimed areas of Egypt which has poor physical properties and lacks of organic materials, and nutrient deficit, thus we could 
use different sources of organic fertilizers and amendments to develop soil and improve its characteristics, which lead to increase yield and help in stopping wheat importing.

Soil amendment includes any material added to soil to improve its properties which can be physical, chemical or biological to allow healthy crop growth (Ussiri and Lal,.2005). However, in agricultural areas, Usage of organic material regularly is a favorable way for improving soil physical and chemical properties, where, soil humus content increase. (Böhme and Böhme, 2006 and Sarwar et al., 2008). Farmyard -manure (FYM), compost and chicken manure known as organic amendment, Currently, biochar is classified as a new soil organic matter amendment (Deenik et al., 2011).

Continuous use of chemical fertilizers, FYM, compost and green manure enhanced the potassium status in the soil and increased potassium uptake by wheat (Verma et al., 2002). Using compost by a rate of 20 and 80 ton ha. ${ }^{-1}$, especially with 80 ton ha ${ }^{-1}$ to soil increased plant nutrient uptake and elements movement in soil which reflex a positive effect on plant growth (Garcia-GIL et al ., 2004). Erhart and Hartl, (2010) reported that the characteristics of the compost influence the mineralization process including the $\mathrm{C} / \mathrm{N}$, and found that 30 to $35 \%$ of the total $\mathrm{N}$ content can be available of the plant in the first year of application and most of the $\mathrm{N}$ release will occur in the first two years after application. Using manure compost or sewage sludge in greenhouse not only increased $\mathrm{N}, \mathrm{P}$ and $\mathrm{K}$ concentrations in soil but also decreased DTPA-extractable $\mathrm{Pb}$ and $\mathrm{Zn}$ contents in $\mathrm{Pb} / \mathrm{Zn}$ tailings and DTPAextractable $\mathrm{Cu}$ contents in soil Chiu and Wong, (2006)

Lehman et al., (2011). stated that the biochar physicochemical properties can cause changes in the soil nutrient and $\mathrm{C}$ availability and uptake of plant, also provide physical protection to microorganisms against predators and desiccation; this may alter the microbial diversity and taxonomy of the soil. Applied biochar as a source of available P, led to beneficial effects on crop production, However, at the highest mineral fertilizer rate, addition of biochar led to about 20-30\% increase in grain yield of wheat compared with the use of the mineral fertilizer alone ( Alburquerque et al., 2013).

Hua Ru et al., (2012) examined the effect of chicken manure on wheat crop, and observed that soil organic matter, total nitrogen, total phosphorus, total Zinc and nitrate $\left(\mathrm{NO}_{3}-\mathrm{N}\right)$, available $\mathrm{P}$ and available $\mathrm{Zn}$ contents significantly increased with increasing rates 15,90 and 150 ton of the chicken manure respectively. The main objectives of this study were to investigate total uptake of NPK by wheat and barley under different application rates of mineral and organic fertilizers in sandy soil, as well as grain Protein yield of $\mathrm{Kg} \mathrm{fed}^{-1}$. 


\section{Materials and Methods}

\section{Study Area and Data Collection}

This research was done in the winter season of 2014-2015 at Mansoura University Farm, Qalabshu region, Dakhlia Governorate, Egypt, to investigate total uptake of N, P and K by wheat (Sakha 68) and barley (Gemeza 123) under different application rates of mineral and organic fertilizers.

Sandy soil, $70 \%$ sand, $11 \%$ silt and $19 \%$ clay. Clay was artificially added within a clayey soil which incorporated with the surface layer, $30 \mathrm{~cm}, 15$ years ago. Qalabshu region mainly depends on drainage water in irrigation process, where its dissolved salts content is less than $2000 \mathrm{ppm}$ in winter season. Data of table (1) reveal some physical and chemical of the used soil and irrigation water in a growing season period.

Table (1) Some Physical and Chemical Properties of the Used Soil and Irrigation Water.

\begin{tabular}{|l|c|c|}
\hline \multicolumn{1}{|c|}{ Analysis } & Soil & Irrigation water \\
\hline EC (dS/m) in soil paste extract & 1.86 & 2.45 \\
\hline $\mathrm{pH}$ in soil paste & 8.5 & 7.5 \\
\hline \multicolumn{3}{|c|}{ Soluble Cations } \\
\hline $\mathrm{Ca}+2$ & $1.80 \mathrm{meq} / \mathrm{l}$ & 2.8 \\
\hline $\mathrm{Mg}+2$ & $5.10 \mathrm{meq} / \mathrm{l}$ & 13.3 \\
\hline $\mathrm{Na}+$ & $9.87 \mathrm{meq} / \mathrm{l}$ & 12.87 \\
\hline $\mathrm{K}+$ & $0.80 \mathrm{meq} / \mathrm{l}$ & 0.496 \\
\hline \multicolumn{3}{|c|}{ Soluble Anions } \\
\hline $\mathrm{HCO}-1$ & $4.13 \mathrm{meq} / \mathrm{l}$ & 4.37 \\
\hline $\mathrm{CL}-1$ & $4.56 \mathrm{meq} / \mathrm{l}$ & 10.2 \\
\hline SO4-2 & $8.82 \mathrm{meq} / \mathrm{l}$ & 14.896 \\
\hline \multicolumn{3}{|c|}{ Available N, P and K } \\
\hline Available N ppm & $17.0 \mathrm{ppm}$ & Not determined \\
\hline Available P ppm & $2.50 \mathrm{ppm}$ & Not determined \\
\hline Available K ppm & $62.0 \mathrm{ppm}$ & Not determined \\
\hline
\end{tabular}

Soil was vertically harrowed twice, land leveling and divided as split plot design. Four organic fertilizer treatments ( 0.0 organic, biochar, $0.5 \%$ of $15 \mathrm{~cm}$ surface layer weight ,compost, $10000 \mathrm{~kg} / \mathrm{fed}$, and Chicken manure, $5000 \mathrm{~kg} \mathrm{fed}^{-1}$ ) occupied main plot while sub plot was occupied with four levels $(50 \%, 75 \%, 100 \%$ and $125 \%$ of recommended $\mathrm{N}, \mathrm{P}, \mathrm{K})$ mineral fertilization, hence the experiment comprise from16 plots with four replicate to be 64 experimental unites. Each plot have a $2.5 \mathrm{~m}$ width $* 10 \mathrm{~m}$ length. Appropriate organic fertilizer was added to the surface of appropriate plots 15 day before planting (15/11/2014) and mixed well by a small rotary plow, then The irrigation was 
done. One week later soil was plowed with a small rotary plow. Sown was done by soaked seeds (one hour for wheat and three hours for barely) were left for two hours after soaking to ease seed distribution as equal, at a rate $60 \mathrm{~kg}$. fed. ${ }^{-1}$.

The used biochar represent the finest byproduct of charcoal manufacture with an EC value of $6.48\left(\mathrm{dSm}^{-1}\right.$ in paste extract), $\mathrm{pH}$ of 12.5 (in paste) and available NPK as 2.36, 13.9, 268 ppm, respectively. It was brought from kom-ombo, abo-Elmatameer district, Elbehara province, Egypt. Compost were manufacture by organic farming project, Faculty of Agriculture, Mansoura Univ. Egypt 2011/2015. This compost with available P extracted with $0.5 \mathrm{M}(\mathrm{NaHCO} 3)$ adjusted at $\mathrm{pH} 8.5$ and was determined at a wavelength $660 \mathrm{~nm}$ by spectrophotometer as described by Olsen and Sommers, (1982). Available K was extracted by ammonium acetate $1 \mathrm{~N}, \mathrm{pH} 7.00$ and determined by using Flam photometer according to Black, (1965). Chemical analyses of biochar, compost and chicken manure were determined according to the standard methods described by the Association of Official Analytic Chemists (A.O.A.C.,1990).

\section{Plant Analysis:}

Total nitrogen was determined by micro Kjeldahl method as described by Hesse, (1971). Total phosphorus was determined calorimetrically at a wavelength of $660 \mathrm{~nm}$ using(Olsen, and Sommers,1982). Total potassium was determined using flame photometer according to Jackson (1972).

\section{Statistical Analysis:}

All data were Statistically analysis According to Gomez and Gomez (1984) using COSTAT-C computer software package. The least significant difference at (0.05) level of probability was used for testing the means of the different variables.

\section{Results and Discussion}

Data presented in table 2 show the individual effect of organic and mineral fertilization on $\mathrm{N}$ uptake Kg.fed-1 of wheat and barley crop. Data revealed that all tested organic amendment significantly increased $\mathrm{N}$ uptake $\mathrm{Kg}$ fed-1 of wheat and barley compared to control, (without organic addition). $\mathrm{N}$ uptake $\mathrm{Kg}$.fed-1 varied 42.73 and $64.90 \mathrm{Kg}$.fed-1 for wheat plant and between 29.37 and $51.79 \mathrm{Kg}$. fed-1 for barley plant. chicken manure treatments increased $\mathrm{N}$-uptake in wheat plant by $35 \%$ compared to biochar treatments, while it increased by $12.5 \%$ compared with compost treatment. These results are in a harmony trend with that of Adeleye et al.,(2010). They stated that " the use of poultry manure in crop production is recommended as it will ensure stability of soil structure; improve soil organic matter status, nutrients availability and high crop yield"

A lower N-uptake by barley plant compared with that of wheat due to lower plant yield and $\mathrm{N}$ content $\%$ of barley than that of wheat. Biochar, compost and chicken manure 
addition increased N-uptake of barley plant by $37 \%, 61 \%$ and $76 \%$ compared with that of 0.0 organic addition. Data of table 2 revealed that mineral fertilization $(50,75,100$ and $125 \%$ ) significantly affect $\mathrm{N}$-uptake by wheat and barley crops. $\mathrm{N}$-uptake by wheat plant increased from 42.01 to $49.03,57.31$ and $64.95 \mathrm{Kg} \mathrm{fed}^{-1}$ while $\mathrm{N}$-uptake by barley crop was increased from 31.07 to $37.83,47.25$ and $52.66 \mathrm{Kg} \mathrm{fed}^{-1}$ due to funeral fertilization dose from $(50,75,100$ and $125 \%)$, respectively.

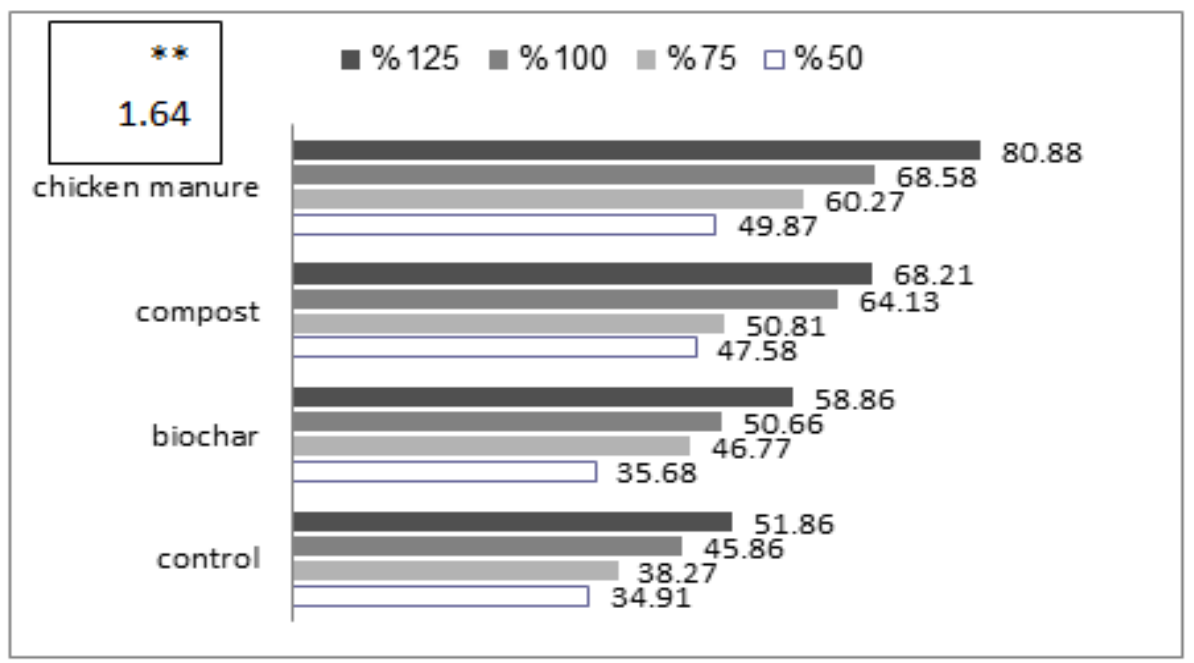

Figure (1) Organic-minerals fertilization interaction effect on wheat $\mathbf{N}$ uptake.

Table(2) Effect of Organic and Mineral Fertilization on Total N, P, K Uptake and Wheat and Barley Grain Protein.

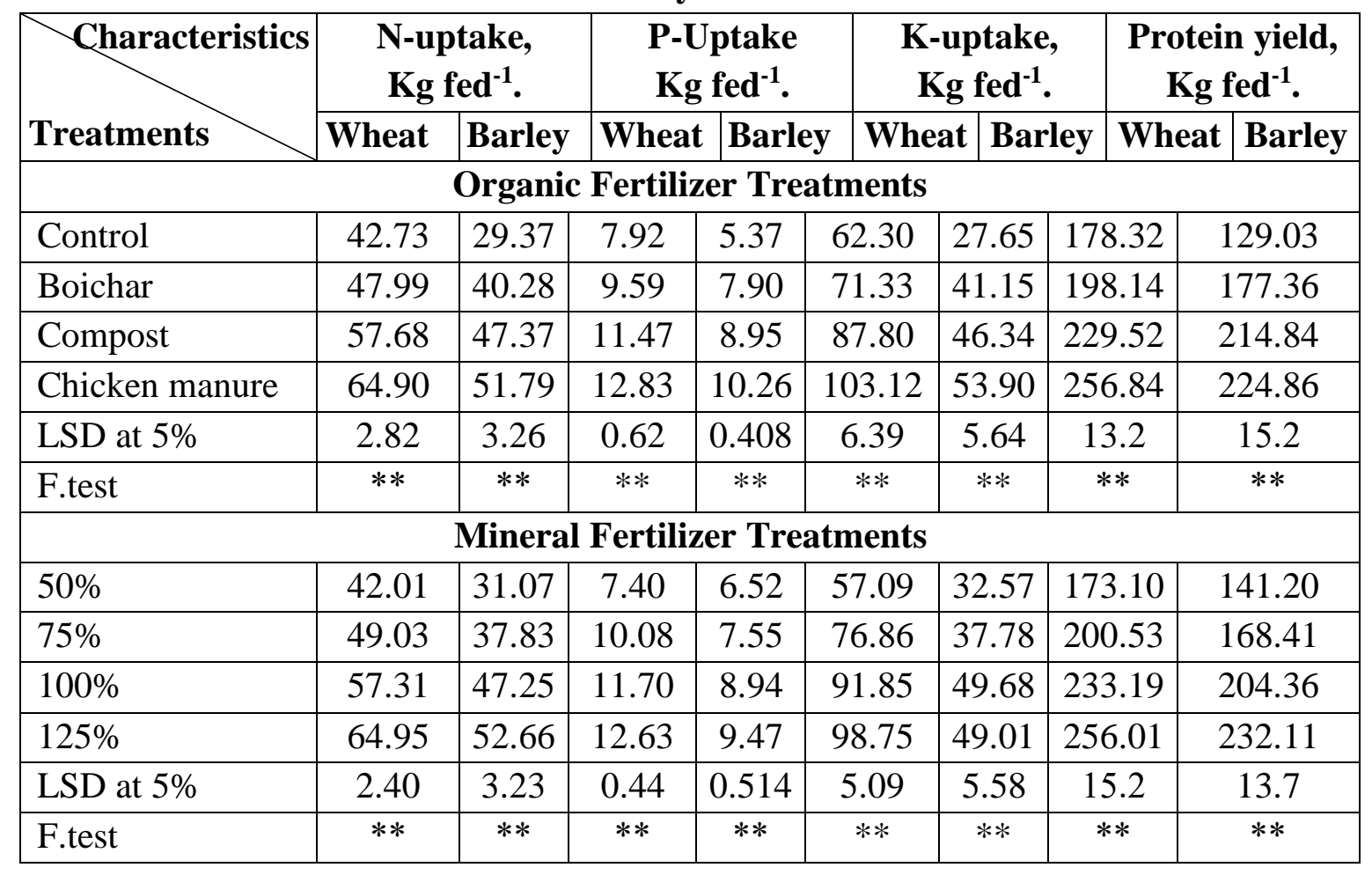


Influence of organic-mineral treatments on $\mathrm{N}$-uptake by wheat and barley crops were shown in Figures 1 and 2, the data statistically indicated that organic-mineral fertilization interaction increased $\mathrm{N}$-uptake of wheat and barley crops. Results of Figures 1 and 2 reveal that chicken manure+125\% mineral fertilizers gave the highest values of $\mathrm{N}$-uptake of wheat and barley 80.88 and $61.60 \mathrm{Kg}$.fed-1 respectively, where the lowest value was given by 0.0 organic matter $+50 \%$ of mineral fertilizers in both cases. This is obtained with Kanchikerimath and Singh, (2001) and Helmy et al., (2013).

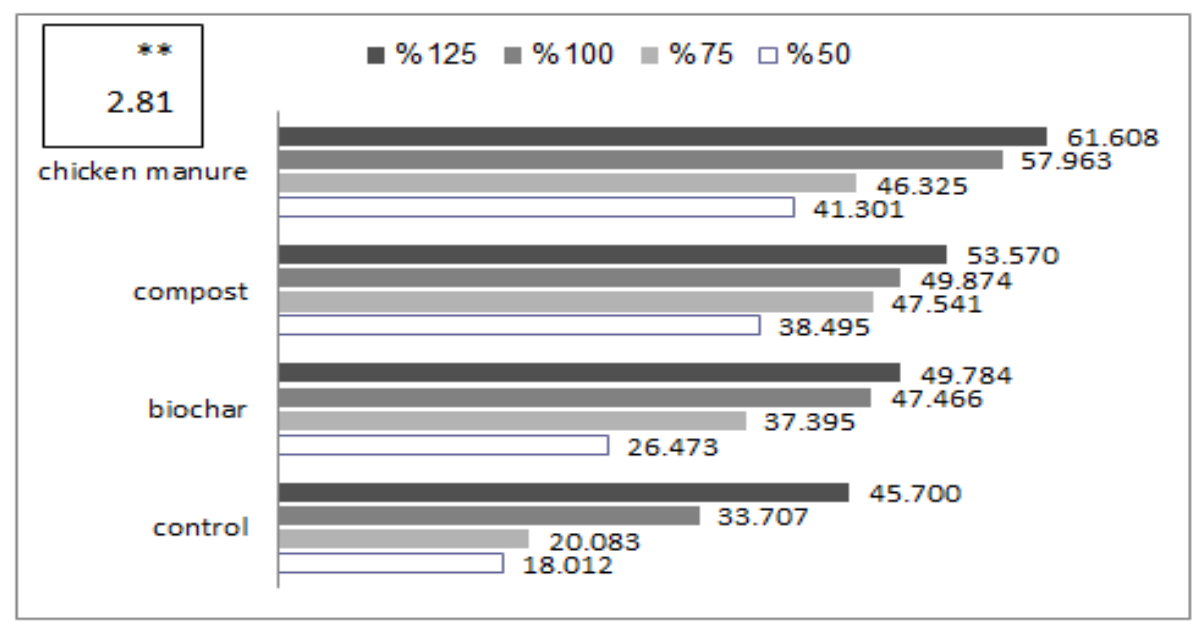

Figure (2) Organic-minerals fertilization interaction effect on barley $\mathrm{N}$ uptake.

Results of table 2 show that each of organic and mineral fertilization effect on wheat and barley crops. Regarding to organic effect, biochar, compost and chicken manure increased

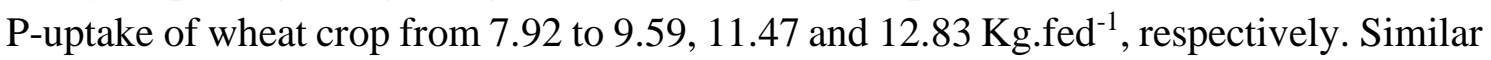
results was also obtained with P-uptake by barley crop, which was increased from 5.37 to $7.90,8.95$ and $10.26 \mathrm{Kg} \mathrm{fed}^{-1}$ due to application of the same organic treatments. These results are in accordance with (Alburquerque et al., 2013).

Concerning to mineral fertilization rate effect on P-uptake by wheat and barley crops, date of table 2 revealed that P-uptake were increased with increasing fertilization dose $(50 \%, 75 \%, 100 \%$ and $125 \%)$ of recommended dose recorded 7.40, 10.08, 11.70 and $12.63 \mathrm{Kg} . \mathrm{fed}^{-1}$ were taken by wheat crop. Whereas with barley the above treatments achieved $6.52,7.55,8.94$ and $9.47 \mathrm{Kg} \mathrm{fed}^{-1}$. It could be concluded that the dose of $125 \%$ mineral fertilizers was the superior one in this respect.

Figure 3 and Figure 4 reveal organic-minerals fertilization interaction effect on wheat and barley $\mathrm{P}$ uptake. The best interaction recorded between chicken manure treatment and $125 \%$ minerals treatments on total P uptake of wheat which was $15.79 \mathrm{Kg}$. fed ${ }^{-1}$, followed by the interaction between compost treatment and $125 \%$ minerals treatments was recorded $13.59 \mathrm{Kg}_{\text {.fed }}{ }^{-1}$, with barley crop the best interaction was found between chicken 
manure and $100 \%$ mineral treatments which gave the highest influenced on total P uptake recorded $11.30 \mathrm{Kg}_{\text {.fed }}{ }^{-1}$, then the interaction between chicken manure and $125 \%$ mineral treatments recorded $11.21 \mathrm{Kg}$.fed-1. Similar results were obtained by other scientists (Eichler-Löbermann et al., 2007; Hua Ru et al., 2012 and Joner et al., 2000).

While. the lowest value on total P uptake of wheat was found between biochar and $50 \%$ minerals treatments where was $6.13 \mathrm{Kg}$ fed $^{-1}$. Treatments of 0.0 organic $+50 \%$ mineral presented the lowest value of total $\mathrm{P}$ uptake of barley plant which was recorded $3.40 \mathrm{Kg} . \mathrm{fed}^{-1}$, compared with other interactions

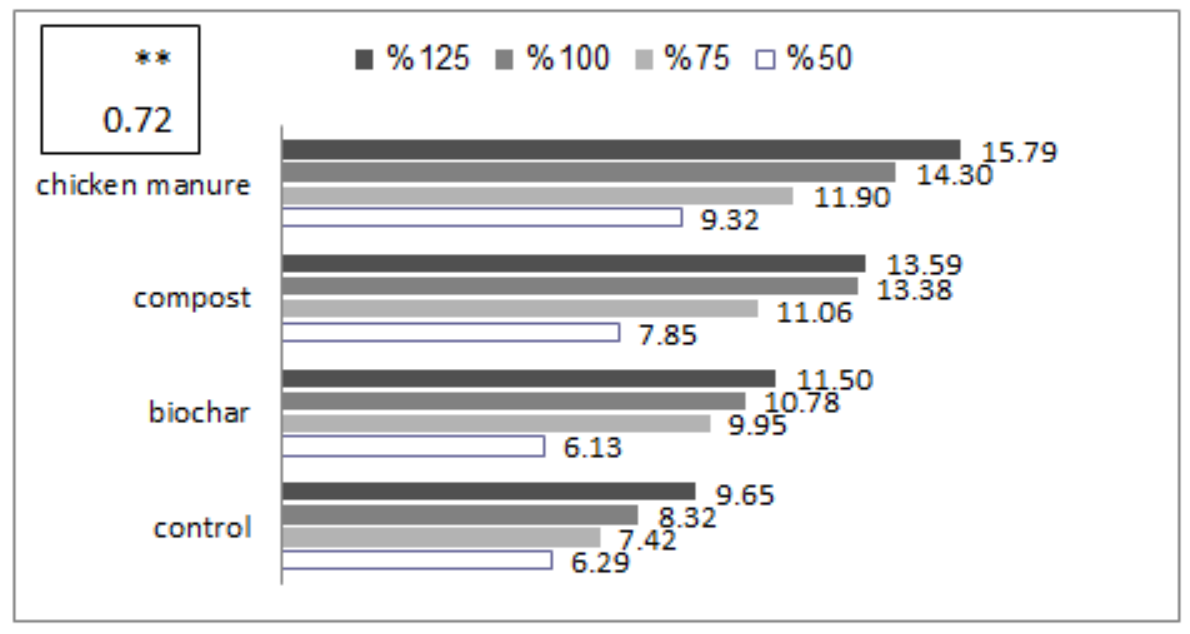

Figure (3) Organic-minerals fertilization interaction effect on wheat $P$ uptake.

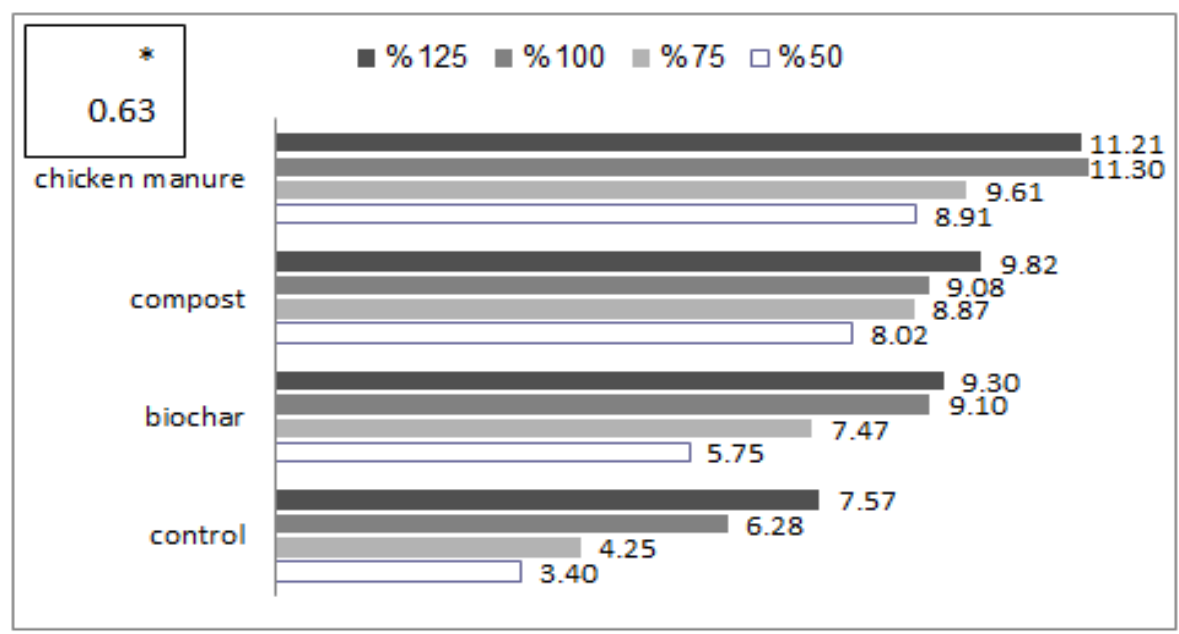

Figure (4) Organic-minerals fertilization interaction effect on barley $P$ uptake.

Data in table 2 show the individual impact of organic and mineral fertilization on total $\mathrm{K}$ uptake Kg.fed ${ }^{-1}$ of wheat and barley crops. Results of all tested organic treatments significantly increased K uptake of wheat and barley crops compared to control, (without organic addition).

134 
The total K-uptake of wheat and barley varied between 62.30 to $103.12 \mathrm{Kg}^{-f_{e d}{ }^{-1} \text { and }}$ 27.65 to $53.90 \mathrm{Kg} . \mathrm{fed}^{-1}$ respectively. It was noticed that biochar, compost and chicken manure addition gave the values of $71.33,87.80$ and $103.12 \mathrm{Kg} \mathrm{fed}^{-1}$ for wheat, whereas they gave $41.15,46.34$ and $53.90 \mathrm{Kg}_{\text {.fed }}{ }^{-1}$ for barley, respectively. The increasing percentage of total K-uptake of wheat and barley due to chicken manure treatments were $65.6 \%$ and $94.9 \%$ compared with control treatments. these results a crossed with AbdelRahman,(2009). He observed an increase of total N,P and K nutrients content in all fertilized plots with compost.

It can be concluded that mineral fertilizer treatments improved total $\mathrm{K}$-uptake in all treatments compared with $50 \%$ of mineral fertilizers. Results in table 2 showed that increasing fertilization dose $(50,75,100$ and 125\%) of recommended dose recorded $57.09,76.86,91.85$ and 98.75 , respectively for wheat whereas, for barley the same treatments were given values of $32.57,37.78,49.68$ and 49.01 , respectively. The increasing percentage of total $\mathrm{K}$-uptake $\mathrm{Kg}_{\text {fed }}{ }^{-1}$ of wheat and barley grains due to $125 \%$ treatment were 73.0 and $50.5 \%$ compared with that of $50 \%$ mineral fertilizers,

Data plotted in Figure 5 and Figure 6 show interactions among organic and mineral treatments on total K-uptake of wheat and barley, the interaction between chicken manure treatments $+125 \%$ minerals treatments gave the highest values of total K-uptake of wheat which recorded $123.54 \mathrm{Kg}$.fed ${ }^{-1}$. While the highest influenced on total K-uptake of barley was found between chicken manure and $100 \%$ mineral treatments which was $71.58 \mathrm{Kg}$ $\mathrm{fed}^{-1}$.

Whereas, the lowest values of total K-uptake of wheat and barley crops presented in the interaction between 0.0 organic addition + and $50 \%$ minerals treatments and this interaction gave $39.04 \mathrm{Kg} . \mathrm{fed}^{-1}$ for wheat and $15.23 \mathrm{Kg} \mathrm{fed}^{-1}$ for barley. Chand et al., (2006) over their initial status, supply of organic and inorganic fertilizer was found most suitable combination with respect to $\mathrm{N}, \mathrm{P}$ and $\mathrm{K}$ availability in soil, and productivity of mint and mustard crop.

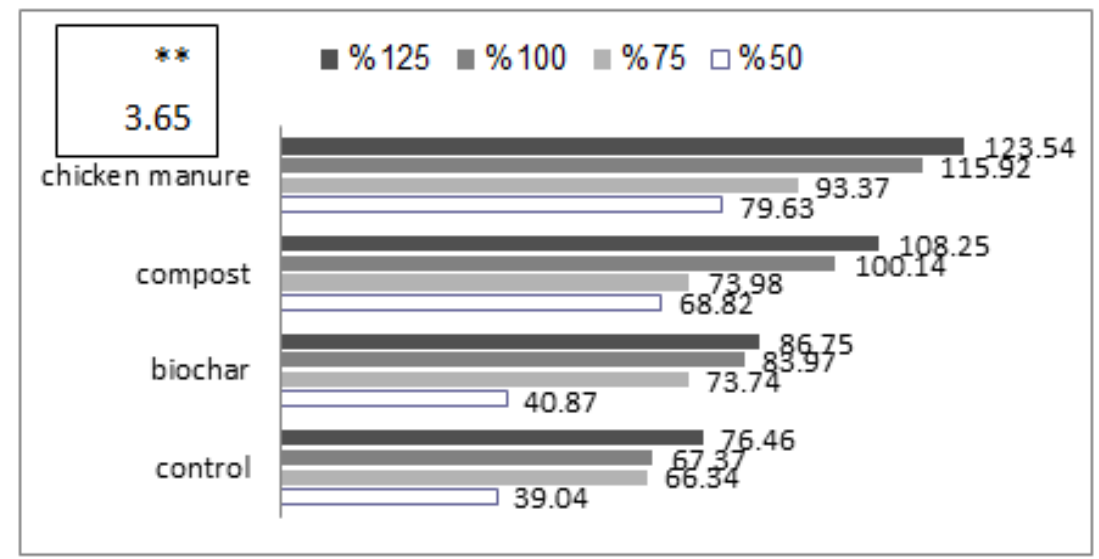

Figure (5) Organic-minerals fertilization interaction effect on wheat $\mathrm{K}$ uptake. 135 


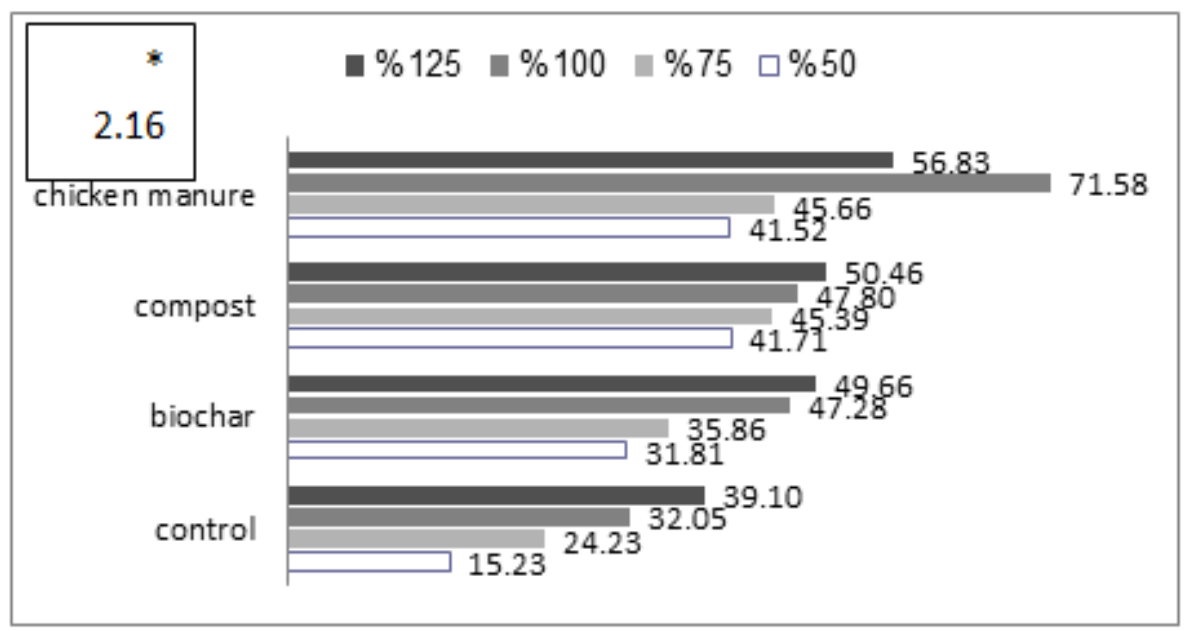

Figure (6) Organic-minerals fertilization interaction effect on barley $\mathrm{K}$ uptake.

Results in table 2 showed that biochar, compost and chicken manure gave grain protein yield of $198.14,229.52$ and $256.84 \mathrm{Kg}_{\text {.fed }}{ }^{-1}$, respectively compared to control (with 0.0 organic addition) for wheat crop. Also, with barley the values of grain protein yield were 177.36, 214.84 and $224.86 \mathrm{Kg}_{\text {. }} \mathrm{fed}^{-1}$ were obtained with the obvious organic treatments, respectively. Chicken manure treatments were the superior and gave the highest values of protein $\mathrm{Kg}_{\text {.fed }}{ }^{-1}$ of wheat and barley which increased by 44.03 and $74.3 \%$ with chicken manure compared with control.

Concerning mineral fertilizer treatments, they increased grain protein yield in all treatments. The results in table 2 illustrated that the increasing percentage of protein in both wheat and barley due to $125 \%$ of mineral fertilizers were 47.9 and $64.4 \%$ compared with that of $50 \%$ mineral fertilizers. Also, increasing fertilization dose $(50 \%, 75 \%, 100 \%$ and $125 \%$ ) of recommended dose recorded 173.10, 200.53, 233.19, and 256.01 $\mathrm{Kg} \mathrm{fed}^{-1}$, respectively for wheat crop. Whereas, with barley they were found to be $141.20,168.41$, 204.36 and $232.11 \mathrm{Kg} \mathrm{fed}^{-1}$, respectively compared with that $50 \%$.

Figure 7 and Figure 8 show that chicken manure $+125 \%$ mineral treatments gave the highest value of protein uptake of wheat and barley which was 310.60 and $278.76 \mathrm{~kg} \mathrm{fed}^{-}$ ${ }^{1}$ comparison with other treatments interaction of both crops. While, interaction between biochar $+50 \%$ mineral fertilizers presented the lowest values of protein yield of wheat which was $150.08 \mathrm{~kg}_{\text {fed }}{ }^{-1}$, on the other hand, interaction between 0.0 organic addition $+50 \%$ mineral fertilizers presented the lowest values of protein yield of barley which was $79.44 \mathrm{~kg} . f e d-1$.These results are in agreement with that of (Abedi et al., 2010 ; Demelash et al., 2014; Ali et al. 2015 and Ahmed et al., 2016). 


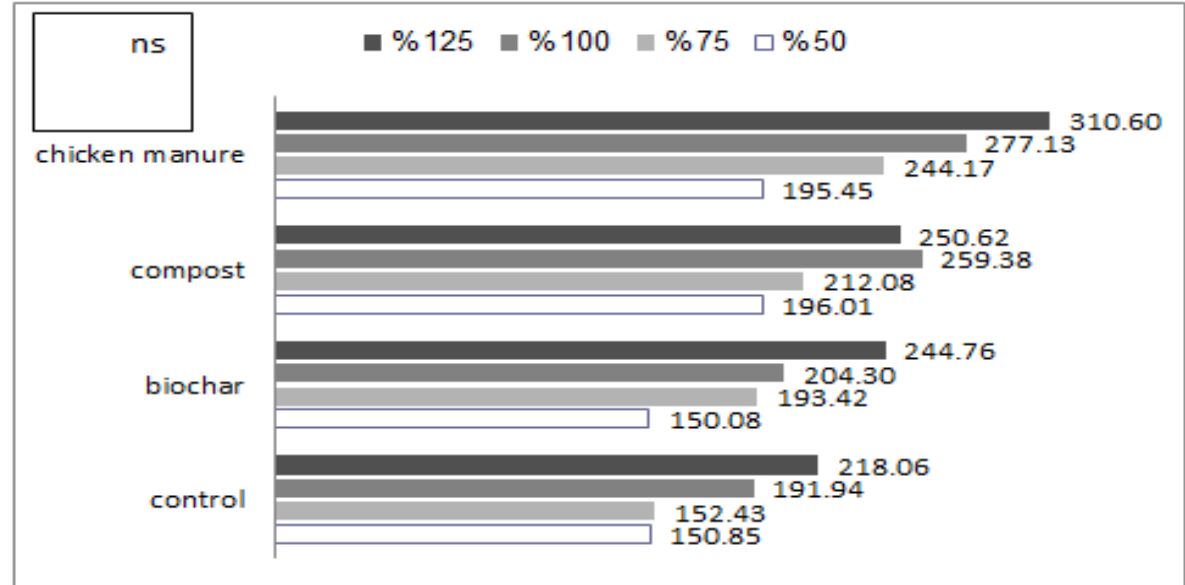

Figure (7) Organic-minerals fertilization interaction effect on wheat protein yield.

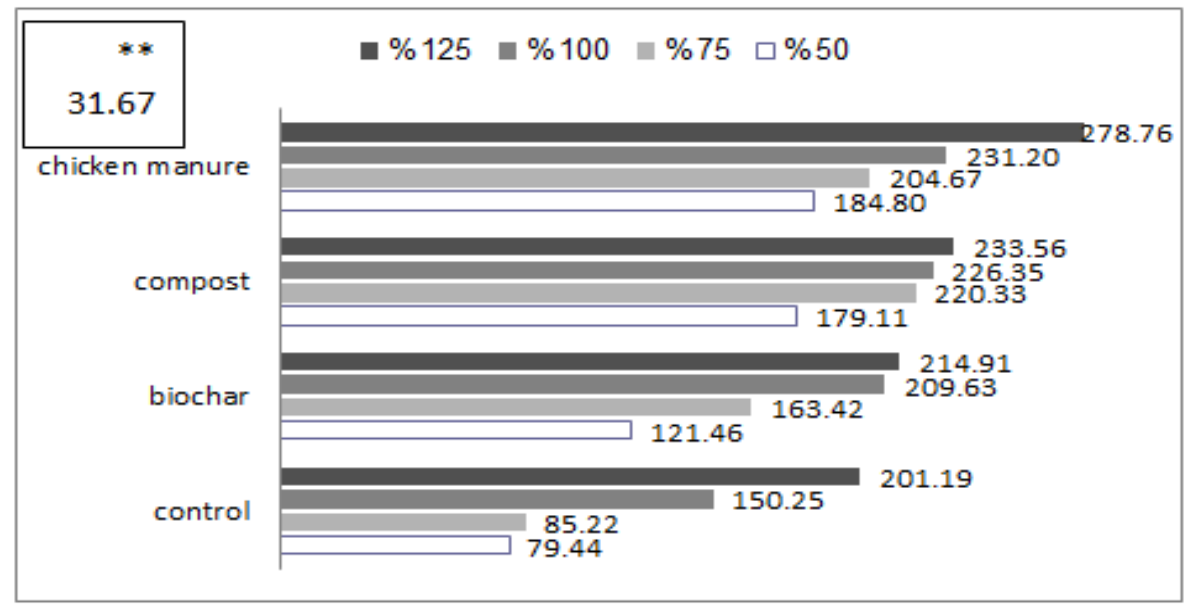

Figure (8) Organic-minerals fertilization interaction effect on barley protein yield.

\section{Conclusion}

It is worthy to conclude that under Egyptian conditions the use of chemical fertilizer, in combination with organic materials, further enhanced the crops yield. Also, organic matter can improve the physical properties of the soil and would have caused increased root development that acted positively in more uptakes of water and nutrients. In a word, the effect of combination of organic materials and chemical fertilizers on seed protein was positive, because of more nutrients availability.

We can use biochar as organic amendment to sandy soil without suffering from the negative effects. The mineral fertilizer recommendation must be changed where the highest value of wheat and barley yield quality and quantity parameters were obtained under chicken manure addition plus $125 \%$ NPK of mineral fertilizers treatment, meaning that $125 \%$ NPK of recommended alone did not sufficiency to yielded the highest yield. 


\section{References}

Abdel-Rahman G. (2009). Impacts of compost on soil properties and crop productivity in the Sahel north Burkina Faso. American- Eurasian J. Agric. and Envi. Sci, 6(2): p.220 226.

Abedi, T., Alemzadeh, A., and S. A.Kazemeini. (2010). Effect of organic and inorganic fertilizers on grain yield and protein banding pattern of wheat.Austr.J. Crop .Sci. 4(6):p.384-389.

Adeleye, E.O.; Ayeni, L.i and S.O. Ojeniyi. (2010). Effect of poultry manure on soil physico-chemical properties, leaf nutrient contents and yield of Yam (dioscorea rotundata) on Alfisol in Southwestern Nigeria.. Journal of American Science.6(10):p.871878.

Ahmed, B. A. M.; Ahmed, F. M. and H. I. Dessougi.(2016). Interactive effect of chicken manure with nitrogen fertilizer and watering regimes on yield and its components of bread wheat. Sch J Agric Vet Sci: 3(3):p.234-237

Alburquerque, J.A., Salazar, P., Barrón, V., Torrent, J., del Campillo, M.D.C., Gallardo, A. and R. Villar. (2013). Enhanced wheat yield by biochar addition under different mineral fertilization levels. Agronomy for Sustainable Development, 33(3):p.475-484.

Ali K., M. Arif, M. T. Jan, M. J. khan and D. L. Jones. (2015). Integrated use of biochar: a tool for improving soil and wheat quality of degraded soil under wheat-maize cropping pattern. Pak. J. Bot., 47(1): p.233-240.

Black, C. A. (1965). Methods of soil analysis. Part 2. Amer. Soci. of Agric., NC Publisher, Madison, Wisconsin.

Böhme, L. and Böhme, F. (2006). Soil microbiological and biochemical properties affected by plant growth and different long-term fertilization. European Journal of Soil Biology, 42(1):p.1-12.

Chand S, Anwar M, and D.D. Patra. (2006). Influence of long-term application of organic and inorganic fertilizer to build up soil fertility and nutrient uptake in mint-mustard cropping sequence. Communications in Soil Science and Plant Analysis. 37(1-2):p.63-76.

Chiu, K. K.; Ye, Z. H. and M. H. Wong. (2006). Growth of vetiveria zizanioides and phragmities australis on $\mathrm{Pb} / \mathrm{Zn}$ and $\mathrm{Cu}$ mine tailings amended with manure compost and sewage sludge: a greenhouse study. Bioresource technology, 97(1): p.158-170. 
Deenik, J., Diarra, A., Uehara, G., Campbell, S., Sumiyoshi, Y. and Jr., M. Antal. (2011). Charcoal ash and volatile matter effects on soil properties and plant growth in an acid ultisol. Soil Science, 176(7): p.336-345

Demelash N.; W. Bayu; S. Tesfaye; F. Ziadat and R. Sommer. (2014). Current and residual effects of compost and inorganic fertilizer on wheat and soil chemical properties . Nutrient cycling in agroecosystems, 100(3): p.357-367.

Eichler-Löbermann B, Köhne S, and D. Köppen ( 2007 ). Effect of organic, inorganic, and combined organic and inorganic $\mathrm{P}$ fertilization on plant $\mathrm{P}$ uptake and soil $\mathrm{P}$ pools. Journal of plant nutrition and soil Science.;170(5):p.623-628.

Erhart, E. and Hartl, W. (2010). Compost Use in Organic Farming. In Genetic Engineering, Bio-fertilization, Soil Quality and Organic Farming, pp. 311-346. New York: Springer Science.

FAO. (2009) . FAO Stat - Agriculture. Food \& Agriculture Organization of the United Nations. Available online at httb://www.fao.org/site/408/Desktop Default. Aspx? ageID $=408$

Gomez, K. A., and A. A. Gomez, (1984). "Statistical Procedures for Agricultural Research”. John Wiley and Sons Inc ., New York

Gracia-Gil, J. C.; Cippe, C. P.; Polo, M. I and A. Sensi.(2004) long term effects of amendment with municipal solid waste compost on the elemental and acidic functional group composition and PH buffer capacity of soil humic acid . Geoderma, 121(1-2): p.135-142.

Helmy, A. M.; Abdel Fattah, M. K and Kh. A. Shaban., (2013) Nitrogen efficiency in barely under saline-sodic conditions as affected by urea, compost and biofertilizer (rhizobium radiobacter sp.). J. Soil Sci. and Agric. Eng., Mansoura Univ, 4(11):p.11691189.

Hesse P. R. (1971). “A Text Book of Soil Chemical Analysis”. Juan Murry (Publisher) Ltd., London

Hua Ru,S.;Zhan,G.Y.;Sun,S,Y and L. Wang. (2012). Effects of chicken manure application on crop yields and soil nutrients accumulation in wheat-corn rotation system. Proceedings of the International Conference on Biomedical Engineering and Biotechnology: p.p 1392-1396.

Jackson, M. L. (1967). "Soil Chemical Analysis Advanced course" . Dept. of Soils, Univ. of Wise. Madison 6, Wishensin, U.S.A. 
Joner, E.J. (2000) .The effect of long-term fertilization with organic or inorganic fertilizers on mycorrhiza-mediated phosphorus uptake in subterranean clover. Biology and Fertility of Soils. 32(5):p.435-440.

Kanchikerimath, M and D. Singh.(2001) Soil organic matter and biological properties after 26 years of maize-wheat-cowpea cropping as affected by manure and fertilization in a Cambisol in semiarid region of India, Agriculture, ecosystems \& environment, 86(2): p.155-162.

Lehmann, J.; Rillig, M. C.; Thies, J.; Masiello, C. A.; Hockaday,W. C and D. Crowley. (2011) Biochar effects on soil biota - A review. Soil biology and biochemistry, 43(9): p.1812-1836.

Olsen, S. R. and L. E. Sommers (1982). "Methods of Soil Analysis", Part2, Chemical and Microbiological properties. Am. Soc. of Agron., Inc. Madison, Wis, USA.

Sarwar G, Hussain N. H, S Schmeisky, M .Muhammad Ibrahim. and E. Safdar. (2008). Improvement of soil physical and chemical properties with compost application in ricewheat cropping system. Pakistan Journal of Botany, 40(1): p.275-282.

Ussiri, D. A. N. and Lal. R.(2005). Carbon Sequestration in Reclaimed Minesoils. Critical Reviews in Plant Sciences, 24(3) :P.151-165.

Verma, T.S., V.K. Suri and Paul. J. (2002). Prescription-based fertilizer recommendations for rice, maize and wheat in different Agro-climatic zones of Himachal Pradesh. Journal of the Indian Society of Soil Science.,50 (3):P. 272-277. 
تأثير الفحم الحيوي والكمبوست وسماد الدواجن والأسمدة المعدنية على الامتصاص الكلي للنيتروجين والبوتاسيوم والفوسفور لمعصول القمح والشعير في التربة الرملية

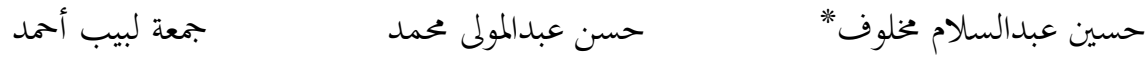

$$
\begin{aligned}
& \text { قسم التربة والمياه,، كلية الزراعة، ق قسم التربة و المياه,، كلية الزراعة، قسم التربة، كلية الزراعة، }
\end{aligned}
$$

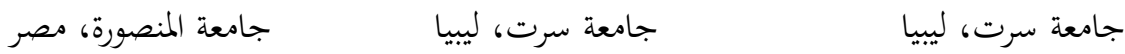

hassin.maklof@su.edu.ly

https://doi.org/10.36602/jmuas.2019.v01.01.11

يعتبر القمح والشعير من أهم المحاصيل للكثير من بلدان العالم، ولا يسبقه في الأهية إلا محصولاً الأرز والذرة، لذلك نفذت بحربتان حقليتان باستخدام تصميم القطع المنشقة في الموسم الشتوي 2014-2015 بمزرعة أبحاث كلية الزراعة بجامعة المنصورة, مصر لتقييم الامتصاص الكلي لكل من النيتروجين والفوسفور والبوتاسيوم بواسطة محصول القمح صنف سخا 68 والشعير جميزة 123 تحت ظروف تسميد من الأسمدة المعدنية

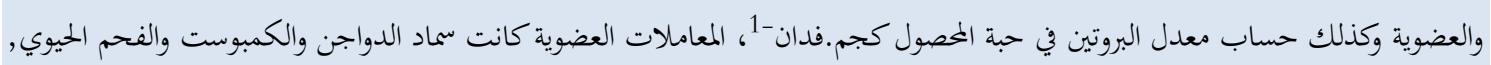

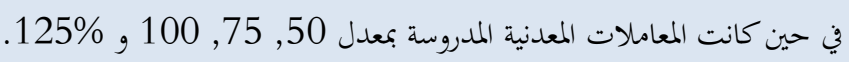

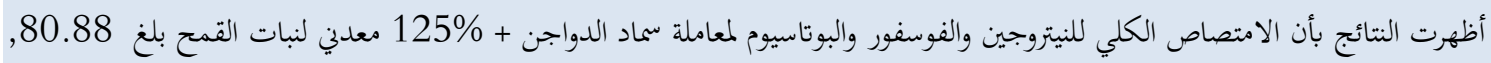
15.79, 123.54 كجم.فدان-1 على التوالي بينما كان في الشعير 61.60, 11.21, 56.83 كجم.فدان-1 على التوالي، بالإضافة إلى أن أفضل معاملة سجلت مع سماد الدواجن + 125\% معدني والذي أعطي أعلى نسبة امتصاص بروتين للمحصول المقدرة 310.60 و 310 و

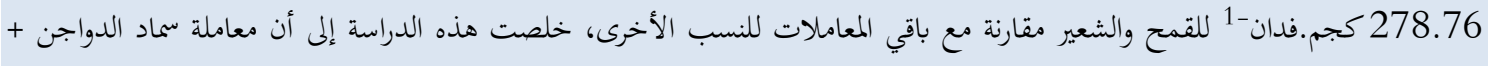
125\% معدني كانت هي الأفضل في معظم الإضافات والذي أعطي أفضل امتصاص كلي للنيتروجين والفوسفور والبوتاسيوم وكذلك أعلى هـلى معدل بروتين مما يؤدي إلى تحسين إنتاجية الخصول وخواص وخصوبة لإنمات التربة. الكلمات المفتاحية: سماد الدواجن- الكمبوست- الفحم الحيوي- الأسمدة المعدنية- القمح- الشعير. 